\title{
A democracia disjuntiva no contexto brasileiro: algumas considerações a partir do trabalho das delegacias de polícia
}

Brazilian disjunctive democracy:

some considerations regarding the police station work

Afinal, o que classifica determinado país como democrático? Seria possível pensar em alguns critérios que fazem com que certo país seja considerado mais ou menos democrático? É possível existir uma democracia de qualidade em que pese o comprometimento de algumas dimensões relacionadas à prestação de serviços essenciais com o de polícia?

Há anos a ciência política tem procurado responder a essas questões formulando teorias sobre como a democracia, enquanto instituição, deveria funcionar: do ponto de vista dos seus procedimentos (método de escolha dos governantes, estabilidade das regras do jogo eleitoral e do próprio processo de renovação dos cargos eletivos); do ponto de vista de sua substância, que estaria intimamente relacionada a forma como as instituições públicas funcionam - se respeitando as regras estabelecidas como balizas para garantia dos direitos civis, políticos e sociais; e, ainda, do ponto de vista da forma como os indivíduos percebem o funcionamento dos respectivos procedimentos e das substâncias da democracia. No que diz respeito aos contrapontos empíricos, diversos são os estudos que têm se ocupado em descrever a forma de funcionamento das instituições estatais com o intuito de identificar quais são as principais práticas que ainda não se encontram em acordo com as

\footnotetext{
É professora adjunta do Departamento de Sociologia e Antropologia e pesquisadora do Centro de Estudos de Criminalidade e Segurança Pública (CRISP), ambos da Universidade Federal de Minas Gerais (Belo Horizonte, MG). E-mail: ludmila.ribeiro@gmail.com.
} 
características mais fundamentais da ideia de democracia e quais seriam as estratégias possíveis de serem implementadas para a mudança dos problemas verificados. Afinal, a ciência política sempre teve na seara de políticas públicas a sua parte mais operativa do ponto de vista prescritivo.

No caso brasileiro, o diagnóstico sobre a qualidade da democracia parece apontar para o fato de que, passados quase trinta anos da institucionalização de um método de escolha de governantes efetivamente democrático, em algumas searas poucos foram os avanços constatados do ponto de vista da institucionalização da substância da democracia. De acordo com Caldeira e Holston (1999, p. 692), isso ocorreria porque, apesar de o Brasil ter criado instituições políticas democráticas com considerável sucesso, e apesar de promulgar constituições e códigos legais com base na ideia de rule of law e no significado dos valores democráticos, o componente civil da cidadania continua seriamente comprometido. Afinal, os cidadãos sofrem violações sistemáticas dos seus direitos.

Em tal cenário, a democracia que teria se institucionalizado no Brasil seria a disjuntiva, já que os requisitos políticos que qualificariam o país como uma democracia convivem com casos cotidianos de injustiça, violência e a impunidade. A categoria disjuntiva seria, portanto, mais reveladora da qualidade da democracia neste país por se opor a definições estritamente políticas da democracia, que ignoram as duas dimensões constituintes do próprio conceito: a abstrata (leis) e a operacional (padrões de funcionamento das instituições responsáveis pelo provimento da justiça), tanto do ponto de vista do Estado (a partir do funcionamento de suas agências) como do ponto de vista da percepção que os cidadãos têm desses padrões de operação (Caldeira e Holston, 1999, p. 692).

A dimensão civil da democracia pode ser considerada como aquela esfera relativa aos direitos, práticas e valores que dão sentido à ideia de liberdade (tanto do ponto de vista negativo como positivo) e à ideia de justiça (como meio de alcance e proteção a todos os outros direitos existentes). $\mathrm{O}$ componente civil da democracia protege o cidadão dos abusos do Estado, garantindo ainda os direitos de associação, comunicação e, assim, de criação da própria esfera pública da sociedade (Caldeira e Holston, 1999, p. 693).

Em uma democracia disjuntiva, os cidadãos participam das eleições livres e associações, mas têm a dimensão civil dos seus direitos limitada 
em três pontos principais. Primeiro, no que diz respeito à impossibilidade de acesso às agências que viabilizariam a proteção e o exercício dos direitos civis (vida, igualdade, liberdade e propriedade), o que seria devido à desconfiança que os indivíduos possuem quanto à capacidade das instituições estatais em materializarem os dispositivos legais. Em tais cenários, quando a liberdade ou a igualdade é ameaçada, a preferência é pela resolução privada de conflitos. Segundo, porque quando a confiança nas instituições responsáveis pela garantia dos direitos civis está presente, a possibilidade de obter serviços é bastante limitada, já que eles são, em geral, caros e pouco compreensíveis a quem possui baixa escolaridade. Terceiro, porque quando a confiança e o acesso são vencidos, há grande probabilidade de uso ilegítimo dos poderes conferidos às instituições estatais por parte de seus profissionais e, dessa forma, a regulação das demandas dos cidadãos termina por ocorrer em evidente oposição àquela idealmente desejada, dado que pela via de autoritarismos ilegais (Rodrigues, 2006, p. 247-248)

Diante desse quadro desolador, seria importante perguntarmos se no Brasil, ainda hoje, é possível afirmar que existe disjunção entre as regras políticas (como os direitos consagrados constitucionalmente) e os procedimentos que dariam substância à dimensão civil da democracia. Ou seja, será que passados mais de 13 anos do texto escrito por Caldeira e Holston (1999), a categoria democracia disjuntiva ainda é a que melhor descreve a realidade brasileira, principalmente, quando a dimensão civil é focalizada?

Dados de pesquisas recentes parecem responder essas questões com um sonoro sim. De acordo com levantamentos realizados pelo escritório das Nações Unidas sobre Crime e Drogas (UNODC), no ano de 2010, as taxas brasileiras de homicídio doloso - que ainda oscilam entre 20 e 24,99 mortes violentas intencionais por 100.000 habitantes - apenas não eram maiores do que a de alguns países da África, da América Central e do norte da América do Sul (Figura 1). Ou seja, a probabilidade de os brasileiros perderem a própria vida, dimensão essencial a ser garantida em qualquer democracia, é muito maior do que a probabilidade observada na maioria dos demais países do mundo, sejam eles de democracia recente ou consolidada. 
Figura 1. Taxa de homicídios dolosos por 100.000 habitantes, no mundo, em 2010 ou no último ano para o qual se possuía informações disponíveis

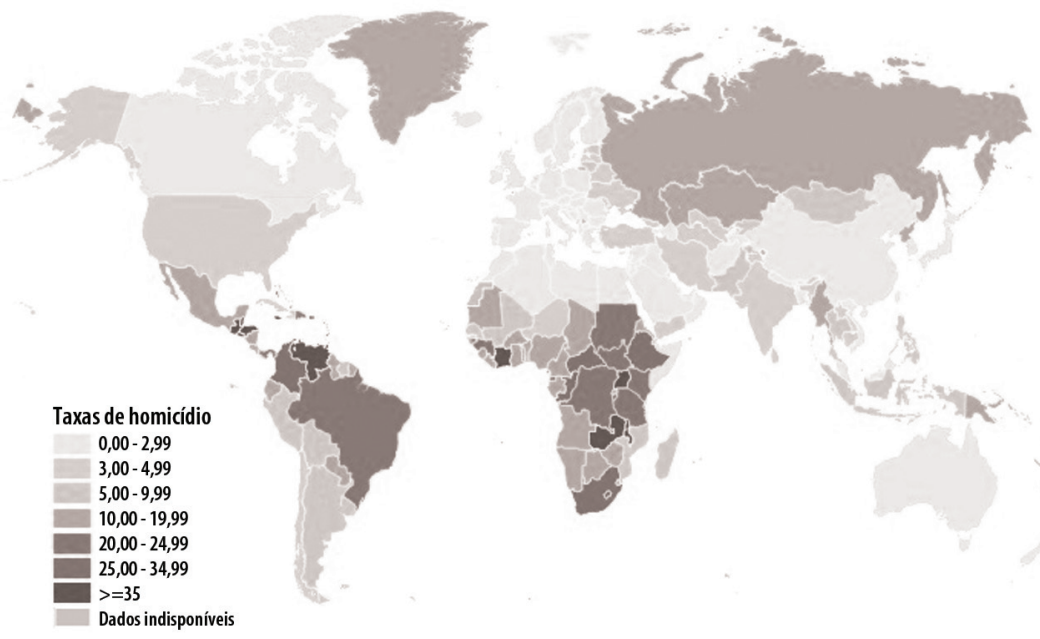

Fonte: UNODC (2011, p. 9)

Quando as agências que se encarregam da garantia dos direitos civis, como as polícias e os tribunais, são focalizadas, o diagnóstico parece ainda mais dramático. Afinal, as polícias militares brasileiras figuram como as que mais matam em todo mundo (Humam Rights Watch, 2009), as polícias civis prestam um atendimento à população qualificado como inadequado (Altus, 2012), o Ministério Público ainda não foi capaz de assumir as funções de supervisão da atividade policial (CEJA, 2012) e o judiciário processa lentamente apenas $1 / 4$ do total de roubos e homicídios dolosos que acontecem nas principais capitais, como é o caso do Rio de Janeiro e de São Paulo (Ribeiro, Machado e Silva, 2012).

Em conjunto, é possível afirmar que tais análises apontam para o fato de que a democracia brasileira, especialmente em sua dimensão civil, continua a ser disjuntiva. Afinal, apesar de regras e procedimentos legais estabelecerem o direito à vida, à igualdade, à liberdade e à propriedade a todos os brasileiros, as agências encarregadas da materialização dessas regras as relativizam todo o tempo, implementando procedimentos que em nada lembram essa prescrição, fazendo com que alguns indivíduos não consigam ter os seus 
direitos civis respeitados e outros tenham essa dimensão essencial de sua cidadania violada pela própria instituição policial.

Além disso, mesmo quando as regras e os procedimentos democráticos são obedecidos pela polícia, a sensação que o indivíduo possui é de que essa obediência não é sustentável, dada a tradicional ausência de compromisso com as regras do jogo democrático que as polícias apresentam. Exatamente por isso, quando vítimas de um crime, os indivíduos tendem a temer a ação policial, rechaçando-a, procurando resolver seus conflitos em âmbito privado. Um indicativo desse fenômeno são os dados que podem ser extraídos dos suplementos de vitimização e justiça da Pesquisa Nacional por Amostra de Domicílios, incluído nos anos de 1988 e 2009. Em quase 20 anos, a taxa de reportagem de crimes como agressões e furtos/roubos à polícia não cresceu substantivamente. Entre as razões mais comumente apontadas para esse procedimento são o descrédito na polícia e o medo de represálias, sendo que o último item foi um dos que mais cresceram como justificativa para não acionamento da polícia nos crimes mencionados (Tabela 1).

Tabela 1. Vitimização, reportagem à polícia e razões para o não registro do caso na polícia, por tipo de crime (apenas adultos maiores de 16 anos, Brasil, 1988-2009)

\begin{tabular}{c|c|c|c|c|c|c}
\hline \multirow{2}{*}{} & \multicolumn{2}{|c|}{1988} & \multicolumn{2}{c}{2009} & \multicolumn{2}{c}{ diferença (2009-1988) } \\
\cline { 2 - 7 } & furto/roubo & agressão & furto/roubo & agressão & furto/roubo & agressão \\
\hline sim & & & & & & \\
\hline sim & $6,3 \%$ & $1,1 \%$ & $7,9 \%$ & $1,5 \%$ & $1,6 \%$ & $0,4 \%$ \\
\hline $\begin{array}{c}\text { por que não reportou } \\
\text { à polícia }\end{array}$ & $32,7 \%$ & $41,7 \%$ & $44,7 \%$ & $48,1 \%$ & $12,0 \%$ & $6,4 \%$ \\
\hline falta de provas & $22,9 \%$ & $5,0 \%$ & $11,6 \%$ & $6,9 \%$ & $-11,3 \%$ & $1,9 \%$ \\
\hline não era importante & $20,8 \%$ & $20,8 \%$ & $23,1 \%$ & $18,2 \%$ & $2,3 \%$ & $-2,6 \%$ \\
\hline não acredita na polícia & $28,4 \%$ & $14,8 \%$ & $36,4 \%$ & $12,9 \%$ & $8,0 \%$ & $-1,9 \%$ \\
\hline $\begin{array}{c}\text { não queria envolver } \\
\text { a polícia / desistiu }\end{array}$ & $9,3 \%$ & $19,6 \%$ & $7,7 \%$ & $16,5 \%$ & $-1,6 \%$ & $-3,1 \%$ \\
\hline medo de represália & $3,4 \%$ & $9,7 \%$ & $11,8 \%$ & $16,6 \%$ & $8,4 \%$ & $6,9 \%$ \\
\hline recorreu a terceiros & $1,4 \%$ & $3,7 \%$ & $3,2 \%$ & $4,7 \%$ & $1,8 \%$ & $1,0 \%$ \\
\hline resolveu sozinho & $5,7 \%$ & $17,2 \%$ & $0,0 \%$ & $19,5 \%$ & $-5,7 \%$ & $2,3 \%$ \\
\hline outro & $7,5 \%$ & $8,8 \%$ & $6,1 \%$ & $4,7 \%$ & $-1,4 \%$ & $-4,1 \%$ \\
\hline
\end{tabular}

Fonte: Pesquisa Nacional por Amostra de Domicílios $(1988,2009)$. 
Considerando esse cenário, a questão que se coloca neste trabalho é de que maneira essas conclusões gerais sobre a disjunção entre regras e procedimentos no âmbito da dimensão civil da cidadania se fazem presentes quando o atendimento prestado por delegacias de Policia Civil é levado em consideração. Problematiza-se, assim, como os indivíduos percebem essa disjunção entre regras e procedimentos e de que maneira esse cenário impacta a própria possibilidade de consolidação da democracia. Em última instância, o que se pretende com este estudo é compreender as principais disjunções entre regras e procedimentos, verificadas no espaço das delegacias de polícia, de acordo com as percepções que os próprios usuários fazem desse serviço.

Como base de sustentação empírica serão utilizados os dados coletados no âmbito da Semana de Visitas a Delegacias de Polícia, um projeto de pesquisa-intervenção social realizado anualmente pela Altus Aliança Global em mais de 20 países do mundo. As diferenças dessa pesquisa em relação às tradicionais residem no fato de que os especialistas possuem papel coadjuvante na condução da pesquisa, selecionando e coordenando grupos de residentes nas áreas atendidas pelas delegacias, para que estes, munidos de um formulário estandardizado, avaliem a qualidade do atendimento prestado por tais instituições. Além disso, há a devolução das avaliações realizadas aos indivíduos pesquisados, a partir da promoção de workshop para a discussão da performance de cada delegacia de acordo com os critérios avaliados e proposição de quais ações podem ser empreendidas pelos policiais para a melhoria da qualidade do atendimento oferecido à população. Por fim, a Semana de Visitas reconhece os bons serviços prestados a partir da concessão de um prêmio às delegacias de polícia que apresentaram as melhores avaliações. Em última instância, trata-se de pesquisa que, em sua dimensão de intervenção, pretende impulsionar a aproximação entre polícia e comunidade e, por conseguinte, o oferecimento de um trabalho policial de melhor qualidade, segundo as regras internacionais que disciplinam o funcionamento de tais instâncias e segundo as demandas e avaliações dos usuários desse serviço.

Para a realização da discussão proposta, este artigo encontra-se estruturado em três seções, além desta introdução. Na próxima seção, são apresentados os conceitos de democracia procedimental, democracia substantiva e, ainda, a própria ideia de democracia disjuntiva que qualificaria o caso brasileiro. Em seguida, a realidade da Polícia Civil brasileira é exposta a partir dos dados 
coletados no âmbito da Semana de Visitas a Delegacias de Polícia. A última parte do trabalho problematiza de que maneira os conceitos da democracia disjuntiva podem ser utilizados para melhor compreensão do que ocorre nas delegacias de polícia e de quais são as implicações que esse fenômeno possui para a qualidade da democracia no Brasil e, por conseguinte, para a plena institucionalização da dimensão civil de cidadania nesta localidade.

\section{Procedimentos em busca de substância: a democracia brasileira e seus qualificativos}

O ponto de partida da discussão que se pretende realizar neste artigo diz respeito à mudança de regime político do autoritarismo para a democracia, o que ocorreu no Brasil quando os Atos Institucionais, que normatizavam os procedimentos que regulavam a ditadura militar (1964-1985), foram revogados. A essa mudança, seguiu-se a eleição direta para governadores dos estados federados (1982), o movimento das Diretas-Já (1985), a promulgação da Constituição Cidadã (1988) e a primeira eleição direta para presidente da república (1989). Nesse momento, a tônica do discurso político era se a democracia, enquanto procedimento para escolha dos governantes e formulação das regras de governo, seria capaz de se institucionalizar ou se um novo golpe, impedindo que os indivíduos viessem a exercer os seus direitos políticos, levaria o Brasil ao governo de militares novamente.

Analisando o que ocorreu no Brasil nos últimos anos (1985-2012), é possível afirmar que a democracia enquanto método de escolha de governantes ou enquanto procedimento encontra-se institucionalizada. Afinal, desde a eleição de Fernando Collor de Mello à Presidência da República em 1989 e seu impeachment em 1992 diante das comprovadas suspeitas de corrupção, assistiu-se à eleição, por dois mandatos consecutivos, de um presidente oriundo da elite intelectual brasileira e filiado a um partido situado à direita do espectro ideológico (Partido da Social Democracia Brasileira - PSDB), seguida pela eleição também por dois mandatos consecutivos de um presidente oriundo da classe trabalhadora e filiado a um partido situado à esquerda do espectro ideológico (Partido dos Trabalhadores - PT), sendo o momento atual o de governo de uma mulher, oriunda das bases do mesmo partido que o presidente anterior. Além desses marcos, que caracterizam a eleição para chefe do Executivo Federal, foram verificados avanços na própria legislação eleitoral brasileira, a qual passou a impedir que indivíduos processados e 
condenados por crimes contra a administração pública pudessen concorrer para cargos eletivos a partir dos pleitos eleitorais de 2012. Em suma, a existência dos procedimentos democráticos para a escolha dos governantes não parece ser o problema da democracia brasileira.

Contudo, concomitante a essa interpretação da democracia, tem-se desenvolvido outra, que enfatiza esse conceito do ponto de vista do seu valor, de sua substância, destacando que a democracia seria um processo e não um procedimento e, dessa maneira, nunca estaria acabada. Nesse contexto, longe de caracterizar os países em termos binários, como democráticos ou não democráticos dependendo dos procedimentos do jogo eleitoral, os estudos contemporâneos têm procurado compreender quais são os graus de institucionalização da democracia do ponto de vista de substância desse conceito, do ponto de vista de regras e procedimentos que orientam o funcionamento da própria sociedade.

Assim, para que determinado país possa ser considerado como substantivamente democrático faz-se necessária a existência de requisitos como: 1) possibilidade de participação dos cidadãos na definição das políticas públicas; 2) amplos direitos e liberdades, garantidos sem nenhum tipo de distinção a todos os indivíduos; 3) governança efetiva, dada a partir de políticas públicas universalizantes; 4) satisfação dos cidadãos com a democracia; e,5) preferência pela democracia em relação aos demais regimes existentes (Levine e Molina, 2011, p. 3).

No caso de comprometimento de uma ou várias dessas dimensões, a democracia deixaria de ser considerada plena para ser qualificada, de acordo com o grau de comprometimento dos seus preceitos substantivos, de frágil, híbrida, delegativa, incerta, disjuntiva e iliberal (Hagopian, 2011). Em todos esses termos é evidente o descompasso entre as promessas das leis democráticas e o que se efetiva na realidade "da vida como ela é”“": entre os procedimentos que garantem a lisura do processo de escolha dos governantes e a incapacidade das estruturas estatais em funcionar de acordo com os fundamentos de igualdade e liberdade, que estruturam a própria ideia de democracia.

Para Houston e Caldeira (1998), o termo "democracia disjuntiva" seria o que melhor qualificaria o caso brasileiro, dado que o desenvolvimento das instituições políticas democráticas convive com um massivo comprometimento da dimensão civil, a qual se refere às esferas dos direitos, das 
práticas e dos valores que contêm as ideias de respeito à vida, à liberdade e acesso à justiça. Incluir-se-iam também as práticas relacionadas ao controle social das instituições concebidas para viabilizar a proteção das liberdades individuais e da justiça. Nesse cenário, a grande disjunção diz respeito ao fato de que as instituições que deveriam garantir a substância da democracia em sua dimensão civil (polícias e tribunais de justiça) seriam as primeiras a violarem essas premissas.

Em sua pesquisa inicial, Caldeira e Holston destacavam que, apesar do sucesso do Brasil na institucionalização da democracia política, no âmbito civil, esse país ainda experimentava grandes óbices à institucionalização da própria ideia de Estado de Direito (Caldeira e Holston, 1998, p. 265). Na atualidade, esse argumento pode ser reificado pelos dos dados do Rule of Law Index (RLI). ${ }^{1}$ Desenvolvido pelo World Justice Project ${ }^{2}$, esse índice é resultado de uma série de mensurações objetivas, balizadas pela opinião de especialistas em cada seara, sobre a capacidade das instituições estatais em efetivar a democracia do ponto de vista procedimental e substantivo.

Composta por oito fatores (Quadro 1), a mensuração do RLI permite qualificar o tipo de democracia verificado de um determinado país, de acordo com as pontuações por ele recebidas em cada uma das dimensões fundamentais (civis, políticas e sociais). Em última instância, esse índice permite identificar as searas nas quais determinadas regras e procedimentos ainda precisam ser melhorados, do ponto de vista da sua formulação ou institucionalização, para que o país não tenha a sua democracia qualificada por adjetivos como inacabada, disjuntiva, incompleta ou até mesmo autoritária.

A pontuação alcançada pelo Brasil no Rule of Law Index de 2011 (Quadro 1) indica que entre as oito dimensões consideradas, aquela na qual o país obteve pior desempenho foi a que diz respeito à não efetividade do país na garantia da ordem e da segurança (categoria na qual o país ocupa o $51^{\circ}$ lugar entre os 66 países pesquisados) e no funcionamento do sistema de justiça criminal (categoria na qual o país ocupa o 44 lugar entre os 66 países pesquisados).

Para mais informações sobre o Rule of Law Index, acesse: http://worldjusticeproject.org/rule-of-law-index. Organização não governamental com sede em Washington, cujos trabalhos destinam-se a mapear a qualidade da democracia em cada localidade e, com isso, viabilizar projetos de intervenção que garantam a sua melhoria. Para mais informações, acesse: http://worldjusticeproject.org. 
Quadro 1. Resultado do Rule of Law Indexpara o Brasil no ano de 2011, por resultados e posição no ranking

\begin{tabular}{c|c|c}
\hline fatores & resultados & posição no ranking global \\
\hline limitação dos poderes governamentais & 0.61 & $26 / 66$ \\
\hline ausência de corrupção & 0.67 & $24 / 66$ \\
\hline ordem e segurança & 0.62 & $51 / 66$ \\
\hline existência de direitos fundamentais & 0.67 & $25 / 66$ \\
\hline governo aberto (transparência) & 0.51 & $30 / 66$ \\
\hline sistema de regulação efetivo & 0.57 & $26 / 66$ \\
\hline sistema de justiça civil efetivo & 0.59 & $24 / 66$ \\
\hline sistema de justiça criminal efetivo & 0.48 & $44 / 66$ \\
\hline
\end{tabular}

Fonte: Rule of Law Index (2011)

Tal como adiantado, as mensurações do Rule of Law Index reificam as descrições de Caldeira e Holston $(1998,1999)$ da democracia brasileira, pois destacam o bom desempenho das dimensões políticas e sociais da democracia brasileira vis-à-vis a incapacidade desse Estado em garantir a ordem, a segurança e o adequado funcionamento do sistema de justiça criminal. O quadro se torna ainda mais dramático quando se adicionam a essa mensuração: os constantes episódios de privatização da justiça ${ }^{3}$; a escalada da criminalidade violenta ${ }^{4}$ e dos crimes cometidos pelas organizações policiais ${ }^{5}$; a criminação dos pobres ${ }^{6}$; e o apoio massivo às medidas ilegais ou autoritárias de controle

\footnotetext{
3 Como é o caso do fenômeno das milícias, denominados enquanto tais os grupos de agentes armados do Estado (policiais, bombeiros, agentes penitenciários etc.) que controlam comunidades e favelas, oferecendo "proteção" em troca de taxas a serem pagas pelos comerciantes e os residentes. Recentemente, esses grupos passaram também a lucrar com o controle monopolístico sobre diversas atividades econômicas exercidas nestes territórios, como a venda de gás, o transporte alternativo e o serviço clandestino de TV a cabo. Para mais detalhes sobre os padrões de configuração e atuação desses grupos, ver Cano e Duarte (2012).

4 Nesse sentido, ver mapa da violência no Brasil (2012), que destaca o fato de este país ainda possuir taxas de homicídio doloso superiores a 10 por 100.000 habitantes, o que faz com que tal localidade ainda seja considerada como vivenciando uma epidemia de homicídios.

5 É o caso dos autos de resistência, que são as mortes praticadas pelas organizações policiais contra civis. As recentes pesquisas denotam que poucos são os casos em que existe qualquer tipo de investigação para se verificar em que medida tais resultados representam em verdade excessos da força policial e que, por isso, estariam mais adequados a regimes de exceção do que a regimes democráticos. Em boa medida, o argumento de Misse (2011) é o de que, como essas ações policiais atingem "bandidos", cuja vida se pode retirar sem qualquer tipo de procedimento democrático anterior, elas terminam legitimadas e, dessa forma, autorizadas.

6 A criminalização dos pobres seria dada pelo viés da ação policial, excessivamente focada em jovens do sexo masculino, pretos e pardos e residentes em favela. Apesar de esse debate ser bastante antigo
} 
do crime e da desordem ${ }^{7}$. Esses dados deixam evidente a disjunção existente entre as regras democráticas (que deveriam garantir direitos civis a todos os indivíduos) e os procedimentos das agências estatais que, apesar de serem as responsáveis pela garantia de tais direitos, são as primeiras a violá-los.

O efeito mais deletério dessa incapacidade das instituições estatais brasileiras em efetivar a ordem e a segurança e em garantir o adequado funcionamento da justiça criminal é o fato de que os indivíduos terminam por não considerar a polícia como uma agência capaz de garantir a lei, os direitos e a própria cidadania quando veem a sua vida, a sua liberdade ou a sua propriedade ameaçadas (ver Tabela 1). Como os cidadãos brasileiros não podem depender das instituições estatais para alcançar os seus direitos, tanto no sentido de proteções como no sentido de imunizações, diante de qualquer problema que demande a intervenção dessas agências, outras soluções são buscadas, ainda que sejam ilegais.

As polícias teriam uma importância adicional nesse cenário por serem a porta de entrada do sistema de justiça criminal. Essas são as primeiras agências às quais os cidadãos deveriam recorrer sempre que se sentissem ameaçados em sua vida, liberdade, propriedade ou igualdade. Soma-se a isso o fato de que um trabalho policial inadequado compromete o próprio trabalho judicial. Afinal, no âmbito criminal, o devido processamento dos ilícitos apenas pode ocorrer de acordo com as regras do Estado Democrático de Direito se o trabalho policial for bem completado ${ }^{8}$.

Contudo, quando apenas essa agência é eleita como contraponto empírico, as disjunções entre as regras - consagradas na constituição e nos tratados de direitos humanos dos quais o Brasil é signatário - e os procedimentos - verificados no cotidiano das delegacias de polícia - tornam o desrespeito à dimensão civil da democracia ainda mais evidente. Apenas para se ter uma ideia da dramaticidade desse fenômeno, cumpre destacar as principais conclusões dos estudos sociológicos que procuram descrever o que acontece quando um indivíduo se dirige a uma delegacia de polí-

nas ciências sociais brasileiras (Coelho, 1978), ainda hoje constata-se que poucas foram as iniciativas realizadas no sentido de alterar esse modus operandi das organizações policiais.

Nesse sentido, ver Campos (2010), sobre a aprovação da legislação penal de emergência como tentativa de conter a escalada de crimes.

8 Nesse sentido, Cano e Duarte (2012) destacam que os casos de homicídio doloso cuja autoria e materialidade foram adequadamente comprovadas pelo inquérito policial tendem, em sua quase totalidade, a lograr sucesso no âmbito judiciário com uma sentença, seja ela de absolvição ou de condenação. 
cia para registrar um crime ou uma queixa referente a alguma violação de direito (Sinhoretto, 2011). Primeiro, entre os estudos que avaliam as condições e a receptividade desse espaço, é destacada a dificuldade do indivíduo em conseguir chegar a algum profissional que se disponha a ouvir o seu caso. Superada essa barreira, geralmente, o funcionário público que recebe o problema encaminha o indivíduo para o delegado de polícia, o qual, em razão de sua proximidade com o cotidiano do cidadão médio, tende a extrapolar a função legal de registro de ocorrências criminais e investigação de delitos, arbitrando conflitos no exercício da tradicional e extralegal função social da polícia. E, para justificar a sua ação como legítima, os próprios delegados afirmam que agem dessa maneira em razão da inoperância das demais instâncias do sistema de justiça criminal. Afinal, para eles, a polícia deve "resolver" todos os conflitos que chegam ao seu conhecimento porque esse é um dos únicos serviços públicos "que funciona 24 horas do dia, nos bairros, atendendo todo tipo de problema social, enquanto juízes e promotores são inacessíveis" (Sinhoretto, 2011, p. 123). Assim, em nome de uma suposta eficiência na administração do conflito, o próprio agente da polícia nega ao indivíduo a possibilidade de acessar a instância judicial, que é a esfera com competência e treinamento específico para desempenho dessa atividade.

A essa disjunção inicial soma-se outra variável que, no conjunto da equação, dificulta a institucionalização da substância da democracia em sua dimensão civil: as ações estatais diferenciadas de acordo com o perfil do sujeito em questão. Assim, em desacordo com o prescrito pela lei, as agências policiais realizam a atividade de "inseticida social" executando sumariamente os "bandidos" (Misse, 2010). E talvez o que cause mais espanto seja o fato de que essas ações contam com grande apoio da população em geral e da elite em especial, o que termina legitimando o desrespeito aos direitos e garantias fundamentais individuais em nome da manutenção da ordem. Nesse contexto, os indivíduos parecem se esquecer de que essa forma de manutenção da ordem é bastante frágil e constantemente ameaçada pelas próprias incursões ilegais dos agentes da lei (Misse, 2011).

O efeito mais perverso dessa disjunção entre procedimentos e substância, entre lei e realidade é que, qualquer que seja a díade em questão, a polícia não é facilmente associada ao que se denomina "rule of law", requisito in- 
dispensável para a institucionalização da democracia substantiva em sua dimensão civil.

Contudo, o que pensam os cidadãos sobre essa disjunção? Como eles avaliam a qualidade do serviço que as polícias oferecem à comunidade? Será que há a reificação das conclusões de pesquisas acadêmicas sobre a forma como a Polícia Civil atua? Ou, ao contrário, as impressões decorrentes de experiências de avaliação do trabalho policial indicam que a disjunção entre normas e práticas consagradas na literatura não se faz presente nas percepções dos indivíduos que visitam as delegacias de polícia? Em suma, será que os indivíduos, quando chamados a opinar, concordam que a democracia se apresenta em sua forma disjuntiva no cotidiano das delegacias de polícia ou será que eles rechaçam essa ideia?

Na tentativa de responder a essas perguntas, a seção seguinte apresenta os dados coletados no âmbito da Semana de Visitas a Delegacias de Polícia. Com isso, espera-se ser capaz de problematizar de que maneira os adjetivos empregados na qualificação da democracia brasileira se fazem presentes na rotina diária da Polícia Civil na visão dos próprios cidadãos.

\section{As interpretações que os indivíduos fazem da cidadania que se exerce nas delegacias de polícia}

Para a análise do padrão de operação das delegacias de polícia brasileira e problematização da maneira como essas agências operam de acordo com a ideia de democracia disjuntiva, serão utilizados os dados da Semana de Visitas a Delegacias de Polícia, coletados para o ano de 2010.

A Semana de Visitas a Delegacias de Polícia é uma pesquisa-ação coordenada pela Altus Aliança Global ${ }^{9}$, com os seguintes objetivos: 1) coletar informações sobre a qualidade do serviço oferecido pela polícia aos cidadãos; 2) permitir que os membros da comunidade atendida pelas delegacias de polícia conheçam tais unidades e o serviço que os policiais realizam em sua rotina diária; 3 ) oferecer a oportunidade de a polícia conhecer o que pensam os cidadãos sobre os serviços oferecidos pela delegacia e, com isso,

\footnotetext{
As organizações que compõem a Altus são: Centro de Estudos de Segurança e Cidadania (Brasil); Centro de Estudos em Segurança Cidadã (Chile); Fundação CLEEN (Nigéria); Instituto de Desenvolvimento e Comunicação (Índia); Fundação INDEM (Rússia); Instituto de Justiça VERA (Estados Unidos da América). Para mais informações: www.altus.org.
} 
desenvolver ações que visem a sua melhoria; 4) comparar a qualidade do serviço oferecido pelas polícias entre as distintas localidades de um mesmo país e entre os distintos países do mundo; 5) aumentar a visibilidade das boas práticas desenvolvidas por delegacias de polícia e que podem ser replicadas; e 6) conceder um prêmio às unidades que se destacam por oferecer um serviço de excepcional qualidade em seu país.

O grande diferencial dessa pesquisa-ação é o fato de ela envolver os cidadãos como avaliadores da qualidade do serviço prestado pelas delegacias de polícia. Além disso, ao contrário das pesquisas acadêmicas, que muitas vezes se encerram com a coleta e análise de resultados, a parte de ação faz com que as avaliações possam ser úteis para subsidiar as discussões relacionadas à reforma da polícia. Dessa forma, a partir dos dados coletados são realizadas: 1) cerimônias de premiação às unidades que se destacam por oferecer um serviço de qualidade compatível com os standards internacionais; e 2) workshops para a discussão de como os chefes de polícia podem aprimorar o serviço prestado aos cidadãos, tornando-o compatível com as determinações legais e os anseios dos próprios indivíduos que avaliaram a qualidade do atendimento prestado.

Para que tal empreendimento pudesse ser realizado de maneira metodologicamente coerente com a lógica da pesquisa social, a Altus desenvolveu um instrumento único, que permite a avaliação das delegacias de polícia em distintos contextos econômicos, culturais e sociais. Para a construção desse formulário, foi mobilizada uma equipe de pesquisadores de vários países, especializados na temática do sistema de justiça criminal. Em conjunto, eles consultaram os diversos tratados internacionais que regulam o funcionamento dessa agência no sentido de garantir o bom tratamento daqueles que buscam o serviço policial em distintos contextos democráticos.

Os itens avaliados pelo formulário da Altus dentro de cada área temática (Quadro 2) foram pensados, portanto, considerando todas as barreiras que um cidadão pode encontrar para registrar a sua demanda desde o momento em que ele chega à delegacia até o momento em que ele recebe (ou não) o atendimento que procura. Além disso, considerando que muitas delegacias de polícia devem lidar com a questão do preso em flagrante ou do detido para investigação/averiguação, o formulário contempla ainda uma série de questões relacionadas às condições de detenção. 


\section{Quadro 2. Dimensões avaliadas pelo formulário da Semana de Visitas a Delegacias de Polícia, de acordo com os documentos consultados}

\begin{tabular}{|c|c|c|}
\hline dimensão & itens avaliados & documentos consultados \\
\hline $\begin{array}{l}\text { orientação } \\
\text { para a comuni- } \\
\text { dade }\end{array}$ & $\begin{array}{c}\text { localização da delegacia; } \\
\text { espaço e facilidades destinadas a servir o público } \\
\text { que chega para registrar um crime ou solicitar } \\
\text { informaçôes; disponibilidade de informaçôes sobre como } \\
\text { reportar um crime ou obter serviços públicos; } \\
\text { staff alocado para servir o público ou registrar crimes }\end{array}$ & $\begin{array}{l}\text { Declaração Universal Dos Direitos Humanos; } \\
\text { art. } 29 \text { do código de conduta; } \\
\text { declaração das Nações Unidas sobre as regras } \\
\text { mínimas de aplicação das medidas não privativas } \\
\text { de liberdade (regras de Tóquio) }\end{array}$ \\
\hline $\begin{array}{l}\text { condições } \\
\text { materiais }\end{array}$ & $\begin{array}{l}\text { grau de organização e limpeza da delegacia; } \\
\text { condições físicas do prédio e da mobília; } \\
\text { condiçōes de trabalho para os próprios policiais; } \\
\text { condiçôes para as vítimas e testemunhas identificar } \\
\text { suspeitos sem serem vistas }\end{array}$ & $\begin{array}{c}\text { declaração das Nações Unidas para a eliminação de } \\
\text { todas as formas de discriminação racial (CERD); } \\
\text { declaração das Nações Unidas sobre as regras } \\
\text { mínimas de aplicação das medidas não privativas } \\
\text { de liberdade (regras de Tóquio); } \\
\text { declaração dos princípios básicos de justiça para as } \\
\text { vítimas de crime ou de abuso de poder (declaração } \\
\text { das vítimas) }\end{array}$ \\
\hline $\begin{array}{l}\text { tratamento } \\
\text { igualitário }\end{array}$ & $\begin{array}{c}\text { condições para as vítimas ou testemunhas de crime } \\
\text { registrarem o seu depoimento em casos em que a } \\
\text { privacidade é importante; } \\
\text { facilidades e condições dos equipamentos disponíveis para } \\
\text { servir às mulheres; } \\
\text { condições de acesso à delegacia de polícia para pessoas } \\
\text { com dificuldade de locomoção (idosos, pessoas com lesões } \\
\text { temporárias ou permanentes); } \\
\text { serviços disponíveis especificamente para grupos } \\
\text { minoritários }\end{array}$ & $\begin{array}{c}\text { art. } 7 \text { da declaração das Nações Unidas para a } \\
\text { eliminaçãa de todas as formas de discriminação } \\
\text { racial (CERD); } \\
\text { convenção das Nações Unidas para a proteção dos } \\
\text { direitos civis e políticos (ICCPR); } \\
\text { código de conduta; } \\
\text { declaração dos princípios básicos de justiça para as } \\
\text { vítimas de crime ou de abuso de poder (declaração } \\
\text { das vítimas); } \\
\text { convenção das nações unidas para a eliminação } \\
\text { de qualquer forma de discriminação contra as } \\
\text { mulheres }\end{array}$ \\
\hline $\begin{array}{l}\text { transparência } \\
\text { e prestação de } \\
\text { contas }\end{array}$ & $\begin{array}{l}\text { informações disponíveis ao público sobre tendências de } \\
\text { crime na área atendida pela delegacia; } \\
\text { informações disponíveis ao público sobre a performance } \\
\qquad \text { da delegacia; } \\
\text { informações disponíveis sobre como registrar uma queixa } \\
\text { em relação ao serviço prestado ou registrar uma reclama- } \\
\text { ção por desvio de conduta do policial; } \\
\text { formas de identificação do staff da delegacia }\end{array}$ & $\begin{array}{c}\text { convenção das Nações Unidas para a proteção dos } \\
\text { direitos civis e políticos (ICCPR) }\end{array}$ \\
\hline $\begin{array}{l}\text { condições de } \\
\text { detenção }\end{array}$ & $\begin{array}{l}\text { condições de segurança da área de detenção; } \\
\text { identificação dos detentos; } \\
\text { condições das facilidades destinadas aos presos para } \\
\text { recebimento de advogados e familiares; } \\
\text { condições sanitárias da área de detenção }\end{array}$ & $\begin{array}{c}\text { art. } 10 \text { da declaração das Nações Unidas para a } \\
\text { proteção de todas as pessoas contra o desapareci- } \\
\text { mento forçado; } \\
\text { convenção das Nações Unidas para a proteção de } \\
\text { todas as pessoas sob detenção ou qualquer forma } \\
\text { de prisão; } \\
\text { convenção das Naçôes Unidas para a proteção dos } \\
\text { direitos civis e políticos (ICCPR); } \\
\text { Declaração Universal dos Direitos Humanos }\end{array}$ \\
\hline
\end{tabular}

Fonte: Altus (2012). 
Conforme mencionado anteriormente, a coleta de informações é feita por pessoas que residem na área atendida pela delegacia de polícia a partir do uso do formulário desenhado pela Altus. Para tanto, são constituídos grupos de quatro pessoas, sendo uma delas o coordenador da visita (acadêmico, mestrando ou doutorando em ciências sociais) e outros três visitantes diversos em termos de sexo, idade, grau de escolaridade e experiência anterior com a polícia. Para se garantir a realização da avaliação da mesma forma em todas as localidades, o representante da Altus em cada país treina os coordenadores regionais, os quais, por sua vez, treinam os coordenadores de visitas e, estes replicam o treinamento aos visitantes, de maneira a capacitá-los na utilização do formulário padrão antes que a visita seja iniciada.

Além disso, a estandardização das respostas é possível pela própria forma de estruturação do formulário de coleta de informações, que contempla 20 questões quantitativas e 10 qualitativas, organizadas em cinco blocos temáticos: 1) orientação para a comunidade; 2) condições materiais; 3) igualdade de tratamento ao público; 4) transparência e prestação de contas; e 5) condições de detenção. As questões quantitativas devem ser respondidas de acordo com a escala likert, atribuindo-se valores entre 1 (totalmente inadequada) e 5 (excelente) a cada um dos itens observados. Há ainda dez questões de livre resposta (abertas) que se destinam a qualificar as notas dadas aos itens anteriores, permitindo o registro de informações detalhadas sobre as impressões dos visitantes.

De maneira geral, o uso de tais procedimentos faz com essa pesquisa-ação possa ser classificada como de inspiração etnometodológica. Afinal, tal como destacado por Giddens e Turner, "os etnometodologistas, em geral, defendem a descrição pormenorizada de processos empíricos, aparentemente desconsiderando o que constituiria a explicação ou a cientificidade da descrição" (Giddens e Turner, 1999, p. 14). Logo, ao se treinarem os visitantes, fazendo com que eles não apenas atribuam notas a cada um dos 20 quesitos avaliados mas também expressem como avaliaram e por que concederam as referidas notas, acredita-se que os dados coletados no âmbito da Semana de Visitas a Delegacias de Polícia podem ser considerados válidos do ponto de vista científico.

Isso significa que, para que a resposta aos formulários obedeça aos mesmos critérios, os visitantes são treinados e, para impedir respostas 
altamente diversas em seu formato, há 20 questões quantitativas que admitem apenas um padrão de preenchimento. Contudo, eles devem ser capazes de precisar as motivações para tais notas, para que o seu raciocínio possa ser reconstituído e, dessa maneira, as pontuações possam ser qualificadas. Com isso, é possível garantir avaliações das delegacias de polícia de acordo com os preceitos da etnometodologia e sem qualquer viés de sexo, idade, grau de escolaridade e experiência anterior com a polícia.

A partir do emprego dessa metodologia foram visitadas 172 delegacias de polícia no Brasil no ano de 2010, distribuídas entre as seguintes cidades: Belém (PA) (21 delegacias), Fortaleza (CE) (21 delegacias), Recife (PE) (21 delegacias), Brasília (DF) (22 delegacias), Rio de Janeiro (RJ) (21 delegacias), Belo Horizonte (MG) (21 delegacias), São Paulo (SP) (22 delegacias), Porto Alegre (RS) (20 delegacias) e Pelotas (RS) (3 delegacias). Essas localidades foram escolhidas por possuírem centros de pesquisa especializados na análise das organizações policiais e capazes de replicar a metodologia da pesquisa, viabilizando a realização das visitas de maneira simultânea ${ }^{10}$.

Durante a visita, que tem duração média de uma hora e meia, os indivíduos apenas observam, conversam e vivenciam a rotina da delegacia de polícia, prestando especial atenção aos critérios considerados pela Altus. Após a visita, cada visitante deve responder ao questionário. Em seguida, eles

\footnotetext{
10 No que se refere à escolha das delegacias avaliadas, o quantitativo foi estabelecido com base em relatórios da Secretaria Nacional de Segurança Pública que apontavam para o número 20 como a quantidade média de delegacias existentes em cada região metropolitana (RM). A partir de uma lista geral de todas as delegacias distritais (ou seja, não especializadas ou aquelas que fazem atendimento ao público de maneira geral) existentes na RM, foi gerada uma lista de números aleatórios, sendo que cada número correspondia a uma delegacia. Os 20 primeiros números foram considerados como elementos integrantes do conjunto principal de delegacias que seriam visitadas pela Altus. As demais foram descartadas. Com o objetivo de se verificar em que medida as delegacias especializadas, de fato, prestam um atendimento distinto daquele oferecido pelas distritais, em cada amostra, foi incluída uma DEAM. Como, em regra, cada RM possui apenas uma, elas foram automaticamente incluídas na amostra. Além das regiões previamente selecionadas, na cidade de Pelotas foi organizado um movimento para que as delegacias fossem visitadas e avaliadas de acordo com a metodologia desenvolvida pela Altus. Como são poucas as delegacias existentes naquela cidade (apenas três), todas foram escolhidas para serem visitadas. Além disso, uma delegacia de São Paulo e uma delegacia do Distrito Federal requereu a visita e uma delegacia de Porto Alegre se recusou a receber os visitantes, o que fez com que os quantitativos dessas três cidades fossem ligeiramente distintos das demais.
} 
discutem as suas opiniões e o coordenador redige um relatório, sumarizando as principais impressões do grupo quanto à experiência ${ }^{11}$.

As pontuações e respostas atribuídas pelos visitantes são, ao final, inseridas em um website privativo da Altus, permitindo-se o cálculo da nota de cada delegacia. Essas pontuações são balizadas pelos relatórios qualitativos para composição da avaliação final de cada unidade, de acordo com os scores apresentados no Quadro 3.

Quadro 3. Intervalos de pontuação para classificação da qualidade do atendimento prestado pelas delegacias de polícia

\begin{tabular}{|c|c|c|c|}
\hline categoria & intervalo de pontos & $\begin{array}{c}\text { quantidade de delegacias } \\
\text { classificadas nessa categoria }\end{array}$ & $\begin{array}{c}\text { percentual de delegacias } \\
\text { classificadas nessa categoria }\end{array}$ \\
\hline totalmente inadequado & 20 - 35 pontos & 26 & 15,12 \\
\hline inadequado & $36-51$ pontos & 67 & 38,95 \\
\hline adequado & $52-67$ pontos & 55 & 31,98 \\
\hline mais do que adequado & $68-84$ pontos & 16 & 9,30 \\
\hline excelente & $85-100$ pontos & 8 & 4,65 \\
\hline
\end{tabular}

Fonte: Altus (2012).

A partir do emprego dessa metodologia, constata-se que, no ano de 2010, um percentual substantivo de delegacias de polícia recebeu avaliação inadequada $(38,95 \%)$ ou adequada $(31,98 \%)$. É importante destacar que $15,15 \%$ das delegacias receberam avaliação totalmente inadequada, 9,3\% receberam avaliação mais do que adequada e apenas $4,65 \%$ receberam uma avaliação excelente (Quadro 3).

Quando as pontuações médias são utilizadas como parâmetro de avaliação, percebe-se que, em geral, o serviço prestado pelas delegacias de polícia no Brasil é inadequado (50 pontos), com destaque para Pelotas, que possui as melhores delegacias do Brasil, e Belém, que possui as piores (Tabela 02, coluna "e").

\footnotetext{
1 Importante destacar que, mesmo após a discussão do grupo, o indivíduo não pode retornar e mudar as notas anteriormente dadas, já que a proposta é avaliar a impressão inicial dos visitantes acerca da delegacia de polícia.
} 
Tabela 2. Pontuação recebida pelas delegacias de polícia brasileiras - IV Semana de Visitas a Delegacias de Polícia / Brasil, 2010

\begin{tabular}{c|c|c|c|c|c|c|c}
\hline $\begin{array}{c}\text { cidade } \\
\text { (em ordem alfabética) } \\
(\mathrm{a})\end{array}$ & $\begin{array}{c}\text { número } \\
\text { de DP } \\
(\mathrm{b})\end{array}$ & $\begin{array}{c}\text { mínimo } \\
(\mathrm{c})\end{array}$ & $\begin{array}{c}\text { máximo } \\
(\mathrm{d})\end{array}$ & $\begin{array}{c}\text { média } \\
(\mathrm{e})\end{array}$ & $\begin{array}{c}\text { desvio } \\
\text { padrão } \\
(\mathrm{f})\end{array}$ & $\begin{array}{c}\text { coeficiente } \\
\text { de variação } \\
(\mathrm{g})\end{array}$ & $\begin{array}{c}\text { valor máximo/ } \\
\text { valor mínimo } \\
\text { (h) }\end{array}$ \\
\hline Belém & 21 & 24 & 54 & 36 & 8 & 0,22 & 2,25 \\
\hline Belo Horizonte & 21 & 26 & 75 & 46 & 14 & 0,30 & 2,88 \\
\hline Brasília & 22 & 31 & 94 & 59 & 16 & 0,27 & 3,03 \\
\hline Fortaleza & 21 & 23 & 67 & 46 & 12 & 0,26 & 2,91 \\
\hline Pelotas & 3 & 50 & 76 & 62 & 13 & 0,21 & 1,52 \\
\hline Porto Alegre & 20 & 27 & 90 & 46 & 14 & 0,30 & 3,33 \\
\hline Recife & 21 & 31 & 100 & 56 & 17 & 0,30 & 3,23 \\
\hline Rio de Janeiro & 21 & 24 & 95 & 52 & 19 & 0,37 & 3,96 \\
\hline São Paulo & 22 & 38 & 93 & 57 & 14 & 0,25 & 2,45 \\
\hline Brasil & 172 & 23 & 100 & 50 & 16 & 0,32 & 4,35 \\
\hline
\end{tabular}

Fonte: Altus (2012).

Para além dos valores médios, é importante considerar a variabilidade das condições de atendimento entre as delegacias avaliadas em cada uma das localidades. Uma forma de se verificar essa variabilidade é calculando quantas vezes o valor máximo de pontuação é maior do que o valor mínimo de pontuação em dada localidade (Tabela 2, coluna " $h$ "). Utilizando essa medida, é possível constatar que as delegacias mais bem avaliadas no país receberam notas 4,32 vezes maiores que as delegacias com pior avaliação. A localidade na qual foi verificada maior variação foi a cidade do Rio de Janeiro, na qual as delegacias mais bem avaliadas possuem notas 3,96 vezes maiores do que as delegacias com pior avaliação. Já a localidade com menor variação foi a cidade de Pelotas, na qual as delegacias com melhor avaliação receberam notas 1,52 vezes maiores que as delegacias com pior avaliação. No entanto, esse resultado deve ser interpretado com cautela, já que Pelotas possui um número substantivamente menor de unidades visitadas que as demais cidades participantes da pesquisa.

No que diz respeito à interpretação substantiva da Tabela 2, é adequado pressupor que, se não existisse uma disjunção entre as regras que orientam 
a prestação do serviço por delegacias de polícia (que são exatamente as consideradas para a elaboração das perguntas do questionário) e procedimentos verificados na rotina dessas unidades, a avaliação realizada pelos visitantes classificaria essas unidades, em média, como adequadas. Contudo, não é isso que ocorre.

A avaliação nacional indica que os serviços prestados pelas delegacias de polícia no país como um todo é inadequado (Tabela 2, coluna "e"). Nessa categoria se encaixam as delegacias de Belém do Pará (média de 36 pontos), Belo Horizonte, Fortaleza e Porto Alegre (todas com média de 46 pontos). As cidades cujas delegacias foram classificadas como "adequadas" são: Rio de Janeiro (média de 52 pontos); Recife (média de 56 pontos); São Paulo (média de 57 pontos); Brasília (média de 59 pontos); e Pelotas (média de 62 pontos). Esses dados parecem indicar que existem diferenças sistemáticas entre as cidades avaliadas no que diz respeito à qualidade do atendimento que as delegacias de polícia oferecem aos cidadãos.

Em um primeiro momento, poder-se-iam atribuir essas diferenças na qualidade do atendimento prestado pela polícia ao próprio grau de desenvolvimento humano. Afinal, os trabalhos sobre impactos da modernização da sociedade na qualidade da democracia têm como uma de suas hipóteses a de que a qualidade do atendimento prestado pelas delegacias de polícia é condicionada ou pelo menos está relacionada ao grau de desenvolvimento humano na localidade. Nesse sentido, o pressuposto testado foi o de que os locais com menor Índice de Desenvolvimento Humano (IDH) apresentariam pior qualidade no serviço policial.

Contudo, o Gráfico 1 indica que Porto Alegre, com elevado IDH, teve o atendimento de suas delegacias avaliado como inadequado, enquanto Recife, com médio IDH, teve o atendimento de suas delegacias avaliado como adequado. A partir desses resultados, é válido concluir que as dissonâncias verificadas entre as promessas da lei e a possibilidade de os cidadãos exercerem os seus direitos civis não parece estar condicionada pela própria qualidade de vida que ele possui. 
Gráfico 1. Qualidade do atendimento prestado pelas delegacias de polícia (2010) e Índice de Desenvolvimento Humano (2000), nas cidades onde a Semana de Visitas a Delegacias de Polícia (2010) foi realizada

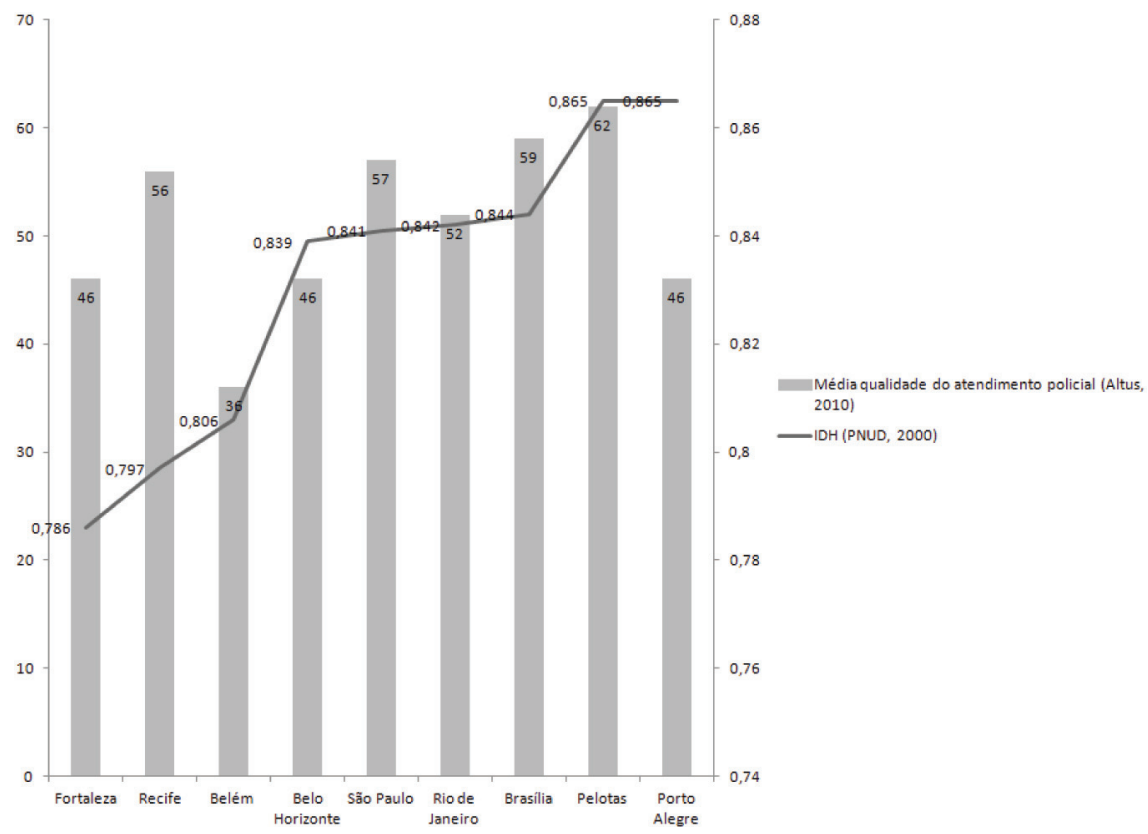

Fonte: Altus (2012), Relatório PNUD (2000).

Na tentativa de encontrar outros elementos para a explicação de quais são as maiores limitações que o indivíduo possui para exercer os seus direitos civis, as dimensões avaliadas pela Altus foram desagregadas e escrutinadas. Afinal, é a pontuação dada a cada dimensão que determina a composição da média final das delegacias de polícia.

Ao desagregar as médias por itens avaliados, é possível verificar que as delegacias visitadas se destacaram nas áreas "orientação para a comunidade" e "condições físicas" e possuem avaliações negativas nos itens "transparência e prestação de contas" e "condições de detenção" (Tabela 3). 
Tabela 3. Pontuação recebida pelas delegacias de polícia brasileiras, por área de avaliação, na IV Semana de Visitas a Delegacias de Polícia (2010)

\begin{tabular}{c|c|c|c|c|c|c}
\hline $\begin{array}{c}\text { cidade } \\
\text { (em ordem alfabética) }\end{array}$ & $\begin{array}{c}\text { média } \\
\text { global }\end{array}$ & $\begin{array}{c}\text { orientação } \\
\text { para a } \\
\text { comunidade }\end{array}$ & $\begin{array}{c}\text { condições } \\
\text { físicas }\end{array}$ & $\begin{array}{c}\text { tratamento } \\
\text { igualitário }\end{array}$ & $\begin{array}{c}\text { transparência } \\
\text { e prestação } \\
\text { de contas }\end{array}$ & $\begin{array}{c}\text { condições } \\
\text { de detenção }\end{array}$ \\
\hline Belém & 36 & 49 & 45 & 33 & 28 & 25 \\
\hline Belo Horizonte & 46 & 56 & 58 & 49 & 39 & 29 \\
\hline Brasilia & 59 & 66 & 68 & 63 & 47 & 50 \\
\hline Fortaleza & 46 & 56 & 58 & 46 & 37 & 33 \\
\hline Pelotas & 62 & 72 & 72 & 70 & 61 & 36 \\
\hline Porto Alegre & 46 & 54 & 58 & 43 & 38 & 38 \\
\hline Recife & 56 & 69 & 65 & 54 & 54 & 39 \\
\hline Rio de Janeiro & 52 & 60 & 63 & 54 & 39 & 47 \\
\hline São Paulo & 57 & 64 & 71 & 57 & 44 & 48 \\
\hline Brasil & 50 & 60 & 61 & 50 & 41 & 39 \\
\hline
\end{tabular}

Fonte: Altus (2012).

As notas recebidas pelas delegacias de polícia em cada uma das dimensões denotam questões interessantes. Afinal, parece que os indivíduos conseguem chegar até a delegacia e que esta possui a infraestrutura mínima para recebê-los. Contudo, os policiais não parecem estar preparados para atender os indivíduos de acordo com as suas especificidades, já que as notas de tratamento igualitário da população e de condições de detenção foram avaliadas como inadequadas.

Além disso, as delegacias também não disponibilizam os insumos necessários para a realização da atividade de supervisão civil do trabalho policial, requisito indispensável para que a democracia possa se consubstanciar em sua dimensão de direitos civis. Essa constatação pode ser evidenciada em detalhes quando as áreas de avaliação são desagregadas em cada um dos seus itens. Interessante destacar que em nenhum item as delegacias brasileiras alcançaram a pontuação mais do que adequada ou excelente (Tabela 4). 
Tabela 4. Pontuação recebida pelas delegacias de polícia brasileiras, por item avaliado, na IV Semana de Visitas a Delegacias de Polícia

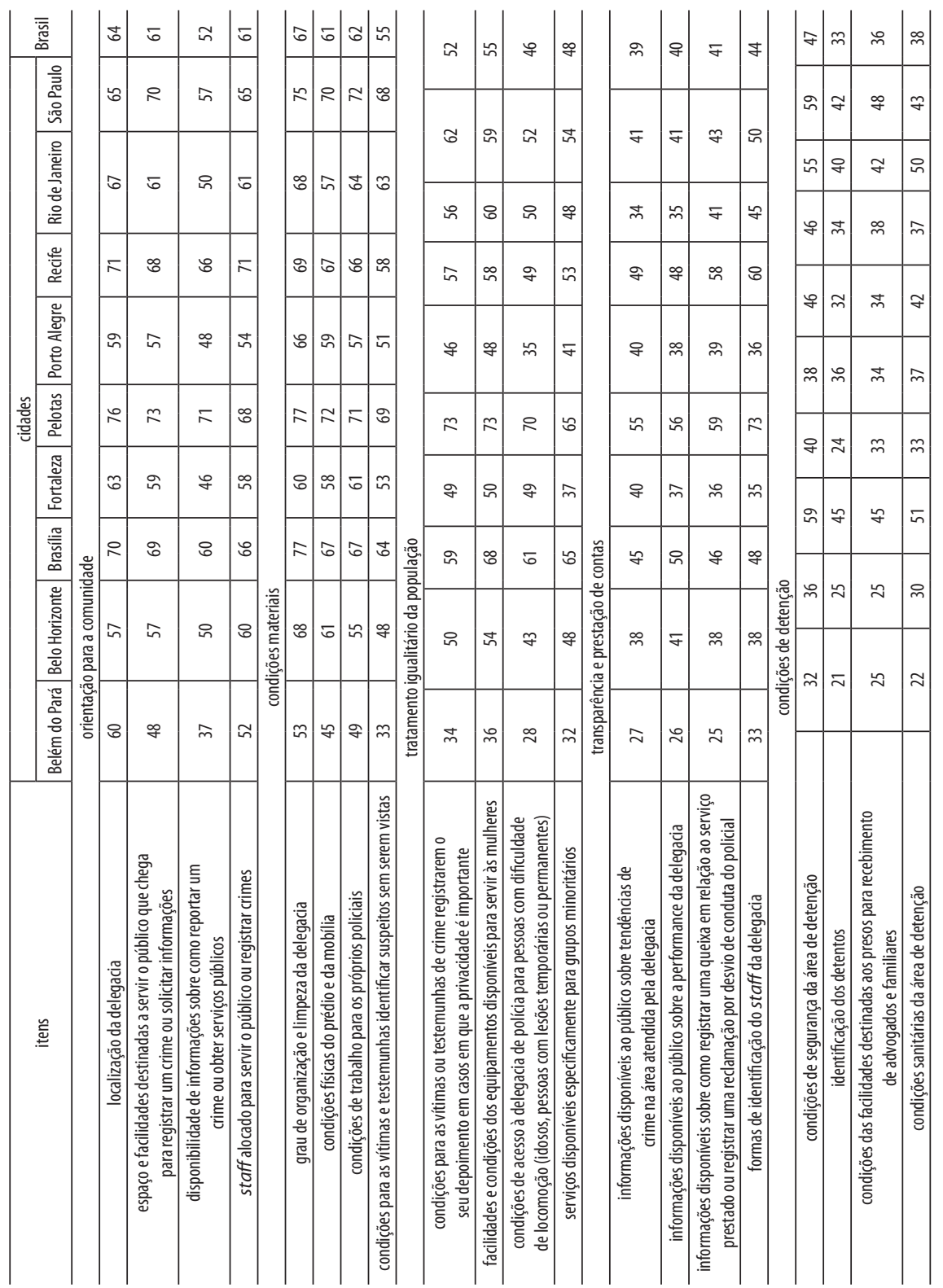

Fonte: Altus (2012). 
Em conjunto, esses dados indicam que as delegacias parecem ser razoavelmente estruturadas, já que, com exceção de Belém, todas as demais cidades receberam nota adequada nesse quesito. Isso significa ainda que, de maneira geral, os indivíduos conseguem chegar até a delegacia e são informados sobre quais são os requisitos que legalmente condicionam ou não o registro do caso. A disjunção entre direitos e possibilidade efetiva de exercício desses também não parece estar vinculada às condições materiais da delegacia, uma vez que as unidades contam com adequada infraestrutura e os policiais possuem mecanismos suficientes para exercício de suas funções.

No entanto, o esquema de cor deixa evidente quais são as searas nas quais a disjunção entre regras e procedimentos substantivos encontra-se localizada. O problema se inicia no tratamento igualitário da população, mostrando a dificuldade dos policiais em adequarem os seus serviços às especificidades do público que procura a delegacia; expande-se pela área de transparência e prestação de contas, indispensável para o exercício de qualquer tipo de controle sobre as instituições estatais; e culmina na área condições de detenção, seara na qual o Brasil sempre foi conhecido, inclusive internacionalmente, por sua incapacidade em transformar as regras legais relacionadas à garantia dos direitos humanos do condenado em realidade (Conectas, 2009).

Portanto, os dados sumarizados no Quadro 1, nas Tabelas 2, 3 e 4 e no Gráfico 1 parecem indicar que a disjunção entre regras e procedimentos substantivos está relacionada com a forma como a própria polícia interpreta a sua função. Contudo, de acordo com Levine e Molina (2011), para além da utilização de critérios objetivos para a mensuração do grau de disjunção entre regras e procedimentos em uma dada seara de direitos derivados da ideia de democracia, é importante considerar ainda a percepção do cidadão acerca da forma como o serviço é entregue pelas agências públicas. Afinal, um dos critérios para avaliação da democracia, do ponto de vista substantivo, é a possibilidade de adequação entre as percepções dos indivíduos e a forma como os serviços públicos são prestados.

Assim, utilizando os dados coletados pela Semana de Visitas é possível indagar se os indivíduos que avaliaram as delegacias de polícia de distintas cidades brasileiras no ano de 2010 concordam com a ideia de que existe uma disjunção entre as regras que deveriam ser observadas pelos policiais para prestação desse serviço e a forma como eles realizam essas atividades. Isso porque, em razão da ausência de uma cultura cívica mais consolidada, 
pode acontecer de os indivíduos perceberem essa disjunção, mas entenderem que ela faz parte do próprio jogo democrático e que, por isso, não caberia a eles questionar essa situação e muito menos pressionar as autoridades para melhoria da qualidade do atendimento prestado pela delegacia de polícia. Com o objetivo de verificar se essa hipótese procede e, dessa forma, lançar novas luzes a um melhor entendimento da qualidade da democracia que se verifica nas delegacias de polícia no Brasil, nos próximos parágrafos serão apresentados alguns dos relatos extraídos das avaliações qualitativas ${ }^{12}$.

No que se refere à possibilidade de materialização das regras contidas nos tratados internacionais quanto ao padrão de funcionamento a ser observado pelas delegacias e, ainda, à própria viabilidade de exercício dos direitos civis em tais espaços, as citações dos visitantes podem ser classificadas em dois grupos. De um lado, encontram-se aquelas que evidenciam surpresa diante do fato de que as delegacias de polícia são locais menos desagradáveis do que o esperado pelos cidadãos e que os policiais não são violadores contumazes de direitos humanos, tal como o senso comum apregoa. Essas citações destacam que, em que pese a disjunção entre regras e procedimentos e o fato de o tratamento oferecido pelas delegacias estar longe de se adequar às promessas da democracia, o cenário encontrado é bem melhor do que o estereótipo comumente divulgado pela mídia.

Chamou a atenção e causou até surpresa ao grupo a limpeza, organização e conservação do prédio. Destaque para a reforma do prédio, promovida pelo advogado titular, utilizando material reciclado arrecada por doação, com uma arquitetura pensada para utilização de luz natural, com o objetivo de poupar energia elétrica. Ressaltaram que delegacias de forma geral têm fama de serem um lugar assustador e que ao entrar nessa tiveram uma impressão bem diferente, com um ambiente amistoso, bom tanto para a população como para quem trabalha. Destacaram que jamais pensaram em encontrar em uma delegacia uma brinquedoteca e uma sala de poesias. E que o quadro com a Declaração Universal dos Direitos Humanos logo na entrada já imprime ao ambiente uma relação de respeito com o cidadão. Como ponto principal todas se referiram positivamente à motivação do delegado com o seu trabalho, a forma com que ele transforma a delegacia em um lugar aberto para a comunidade (Delegacia 157, São Paulo).

12 Para se preservar a identidade dos indivíduos que visitaram as delegacias, foram utilizados os relatórios dos coordenadores da visita sobre as impressões dos visitantes. Além disso, não é apresentado o nome da Delegacia de Polícia, mas um número aleatório que a identifica na base de dados. 
De outro lado, estão as citações que descrevem como os policiais violam a liberdade e, em algumas situações, a própria integridade dos indivíduos que procuram a delegacia ou que nela se encontram detidos. Nessa categoria encontram-se aquelas citações que destacam que a visita nada mais fez do que ressoar o estereótipo comumente difundido das delegacias de polícia como agências que, ao invés de viabilizarem a proteção dos direitos civis, são as primeiras a violá-los.

Enquanto aguardávamos a chegada do delegado, na recepção da delegacia, ouvimos alguns gritos e um barulho de batidas na mesa. Parecia uma repreensão severa a um dos detidos. Era possível ouvir tudo o que se dizia na saleta, cuja porta estava aberta. Destacamos: o delegado falava gritando "Isso aqui é uma delegacia rapá, aqui só tem homem, macho, tá entendendo...?”. Na recepção, os presentes, emudecidos e com os olhos arregalados, limitaram-se a se entreolhar e fazer gestos faciais de espanto por causa de tanta gritaria (Delegacia 01, Rio de Janeiro)

Conforme destacado anteriormente, o formulário da Altus é pensado para que o visitante perceba progressivamente as barreiras a serem transpostas para alcance de um atendimento de qualidade. Exatamente por isso, o primeiro bloco de questões trabalha a inserção/acessibilidade da delegacia na comunidade; o segundo, as condições que os policiais possuem para prestar o atendimento; o terceiro, a sensibilidade da unidade em perceber as diferentes necessidades dos indivíduos que residem na localidade em razão de seu sexo, idade, orientação sexual e grau de escolaridade; o quarto, as informações que a delegacia disponibiliza para que os cidadãos possam avaliar o trabalho policial e, se for o caso, pedir providências em relação aos desvios de conduta; e, o quinto, como a unidade administra a questão da detenção do ponto de vista dos direitos e garantias do preso. Nesse sentido, é interessante destacar como os visitantes vão comparando, progressivamente, os critérios que deveriam ser materializados pela unidade policial, mas que na prática configuram apenas regras formais, muito distantes da realidade.

O primeiro ponto que se destacou foi a fachada do prédio e o seu mau estado de conservação. As 2 visitantes do sexo feminino mostraram notório espanto com relação à conservação do prédio. Uma delas comentou: "Nossa! Se do lado de fora está desse jeito imagina só lá dentro". A outra visitante questionou se seria uma delegacia legal ou se era a tradicional. Ao saber que se tratava de uma delegacia legal ela disse: "Pensei 
que não fosse. Não consigo ver o amarelo da delegacia legal”. Em seguida, a exposição das vítimas especialmente nos casos de violência contra mulher foi observada como outro ponto negativo. Uma critica severa que o delegado fez à delegacia legal diz respeito aos balcões de atendimento. Segundo ele: "as delegacias legais parecem o Mc Donalds. Você chega no balcão e fala o que você quer". Para ele, isso é um ponto negativo, pois não há privacidade para as vitimas de casos como estupro e violência conjugal. "A mulher fica exposta ali, como se já não tivesse sofrido o suficiente". Suas palavras comoveram as 2 visitantes que concordaram prontamente. Outro ponto que incomodou os visitantes negativamente foi a pilha de materiais apreendidos no meio do corredor . Nessa pilha, em maior quantidade estavam balões. Olhar esses itens espalhados pela delegacia incomodou os nossos visitantes. Segundo eles, por mais que a delegacia não esteja bem conservada e não exista investimentos por parte do governo, cabe ao delegado organizar a delegacia. Isso, para eles, passou uma imagem de que o delegado reclamava mas estava acomodado com a situação. Uma das visitantes resumiu bem essa ideia dizendo: "Parece que ele coloca a culpa toda na falta de investimentos e na manutenção pra 'tirar o corpo fora' das suas próprias responsabilidades (Delegacia 04, Rio de Janeiro).

Em conjunto, essas citações indicam que no imaginário dos brasileiros as delegacias de polícia são espaço para o cometimento de todo tipo de arbitrariedade e violação de direitos e, por isso, quando o cenário com o qual os visitantes se deparam é distinto dessa percepção, há uma grande surpresa e, por conseguinte, uma avaliação bastante positiva do serviço policial.

No meu caso, a visita serviu para desconstruir alguns estereótipos negativos a respeito do trabalho policial e, ao mesmo tempo, foi pedagógico no sentido de ter aprendido como funcionam os processos no âmbito de uma DP. Por outro lado, também serviu pra reforçar alguns estereótipos negativos, como a questão do moralismo, a vontade de limpar a área e "empurrar" atividades relacionadas ao sexo para outras áreas (Delegacia 109, Brasília).

A visita a delegacia mudou a visão extremamente negativa que esta instituição possuía para esta equipe, antes da visita eles consideravam este ambiente sujo, sucateado e de péssimo atendimento. Contudo, foi observado exatamente o contrário. Os visitantes destacaram a importância de conhecer este ambiente estigmatizado e poder desconstruir essa imagem que tinham, conheceram melhor a estrutura e os serviços oferecidos a comunidade e a possibilidade de sugerir melhoras para estes servidores (Delegacia 65, Fortaleza). 
Cumpre destacar que em nenhum caso de avaliação positiva da qualidade dos serviços prestados os visitantes disseram que não esperavam algo distinto ou que a delegacia, enquanto instituição democrática, deveria ser capaz de atender a todos que precisam do serviço de acordo com as regras legais. Pelo contrário: em todas as circunstâncias, quando os visitantes constatavam que a delegacia cumpria os requisitos legais, essa realidade era descrita com bastante surpresa.

O primeiro aspecto que impressionou positivamente os visitantes diz respeito ao trabalho de transparência e prestação de contas que a delegacia desenvolve junto à comunidade, a unidade conta com cartazes de combate as drogas e informativos impressos disponíveis para o público sobre tendências de crimes na área da delegacia (golpe do falso seqüestro e assalto na saída de banco), também disponibiliza gráficos sobre o desempenho e o trabalho da delegacia, número de crimes resolvidos, número de inquéritos remetidos, bem como, cartazes com telefones do disque denúncia, da ouvidoria e corregedoria de policia, que explicam como denunciar desvios de conduta da equipe. Vale salientar ainda que todos os funcionários da delegacia estavam devidamente identificados com seus respectivos crachás ou fardas, além do mais, com um intuito de individualizar e obter um reconhecimento imediato por parte da comunidade para com a delegacia, a equipe desenvolveu um logotipo especial para representar a AIS. Outra boa impressão causada nos visitantes, diz respeito à excelente administração da delegacia de polícia, a unidade é gerenciada com capacidade e compromisso, os ambientes são limpos e organizados, decorados com vasos de plantas, uma forma de humanizar o ambiente e deixá-lo mais agradável aos olhos do público e da própria equipe. Ficou evidenciado o respeito pelo usuário e total comprometimento com o trabalho policial, o que resulta em excelentes resultados obtidos por esta unidade policial (Delegacia 116, Recife).

Por outro lado, indivíduos que nunca tinham estado em uma delegacia puderam confirmar estereótipos negativos, já que o serviço prestado era pior do que o esperado. Em geral, nessas falas, são destacadas questões relacionadas ao tratamento diferenciado que essas unidades concedem à população de acordo com a sua condição socioeconômica e, ainda, a falta de capacidade dos policiais em se verem enquanto prestadores de um serviço público.

A impressão geral dos participantes foi péssima. Ficaram decepcionados com a falta de estrutura do prédio, dos móveis e do equipamento e material da delegacia. Relataram 
ainda a questão da falta de identificação da equipe da DP e da completa desorganização do depósito e arquivo devido à falta de espaço (Delegacia 16, Porto Alegre).

Todos os três tinham uma visão negativa do ambiente policial e esta visita apenas confirmou o que pensavam. Algo que impressionou os visitantes foi a extrema falta de organização e condições materiais, que eles achavam que haveria minimamente em um ambiente de trabalho policial (Delegacia 76, Belo Horizonte).

A experiência anterior com a polícia é também outro critério importante de ser destacado quando se analisam as disjunções presentes entre regras e procedimentos substantivos. Isso porque, conforme destacado por alguns visitantes, o tratamento por eles recebido tende a ser diferenciado no momento em que se procura a polícia na qualidade de cidadão vitimizado por um delito e na qualidade de membro de uma equipe que está na unidade para avaliar a qualidade do atendimento prestado pela delegacia.

As impressões desta delegacia, no geral, foram boas. Todos os visitadores eram jovens e observaram muito as condições de atendimento e esclarecimento prestado a população. Um dos meninos, que era negro e mais jovem, comentou que já tinha ido naquela delegacia e que não foi tão bem recebido como durante a visita. Mesmo assim, ele gostou de conhecer a delegacia de uma outra forma (Delegacia 158, São Paulo).

Minha experiência em delegacias foi quando meu irmão foi preso. Eu e minha mãe sofremos grande desrespeito, a sensação que a gente tem é que o máximo que puderem te maltratar eles vão te maltratar, hoje tive uma impressão de que talvez possa ser diferente. Mas eles estão tratando bem a gente, tenho dúvida se eles tratam bem os presos e sua família (Delegacia 100, São Paulo).

Portanto, apesar da existência de regras internacionais regulando o cotidiano das delegacias de polícia, poucas são as unidades visitadas que conseguem transformar esses procedimentos em substância. Para os cidadãos, especialmente após a participação na Semana de Visitas, fica evidente a ideia de democracia disjuntiva, muitas vezes expressa nas observações que eles próprios fazem sobre o que constatam durante a visita: a grande distância entre as regras que orientam a prestação do serviço e o que é verificado na prática. É cediço afirmar que, ao contrário do que a parte de intervenção da pesquisa pretende, as visitas muitas vezes contribuem para a consolidação 
de estereótipos, em especial o das delegacias de polícia, como agências que, longe de viabilizarem o exercício de direitos, são lócus nos quais a violação dessas garantias constitucionais faz parte do "pão nosso de cada dia".

\section{Considerações finais}

A proposta deste artigo foi verificar em que medida a ideia de democracia disjuntiva se faz presente no cotidiano das delegacias de polícia, identificando, assim, os pontos em que a consolidação democrática ainda não avançou no contexto brasileiro.

Dessa forma, o conceito de democracia disjuntiva, entendida enquanto a ausência de conexão entre regras democráticas e práticas substantivas verificadas no âmbito de instituições estatais, foi apresentado e, como contraponto empírico, foram utilizados os dados coletados no âmbito da Semana de Visitas a Delegacias de Polícia de 2010.

Essa pesquisa-ação foi escolhida como base de informação porque um de seus objetivos é fazer com que os usuários ou potenciais usuários do serviço policial avaliem como este é prestado, considerando os standards internacionais (tratados internacionais ratificados pelo Brasil) nas seguintes dimensões: orientação à comunidade, condições materiais, tratamento igualitário da população, transparência e prestação de contas e condições de detenção. Como os visitantes são treinados não apenas para qualificar cada um dos itens que compõem o questionário de acordo com uma escala likert mas também para reproduzir as impressões que tiveram da interação com os policiais e, ainda, as falas daqueles com quem entraram em contato, é possível afirmar que os dados coletados são válidos do ponto de vista científico e, ainda, observam os princípios da etnometodologia em seu processo de coleta.

A partir do uso dessa metodologia foi possível constatar que, quando as delegacias são ordenadas de acordo com os scores alcançados por cada uma (Gráfico 2), fica evidente que a grande maioria concentra-se no critério "inadequado", no qual caem aquelas que receberam entre 36 pontos (28a Delegacia de Polícia no rank) e 51 pontos (95ª Delegacia de Polícia no rank). Interessante notar que, quanto maior o score, menor o número de delegacias que se enquadram na categoria. Além disso, Belém, Belo Horizonte, Fortaleza e Porto Alegre têm poucos casos que podem ser classificados como mais do que adequado ou excelente (68 pontos e mais). 
Gráfico 2. Dispersão da avaliação final das delegacias de polícia no Brasil, na Semana de Visitas a Delegacias de Polícia, 2010

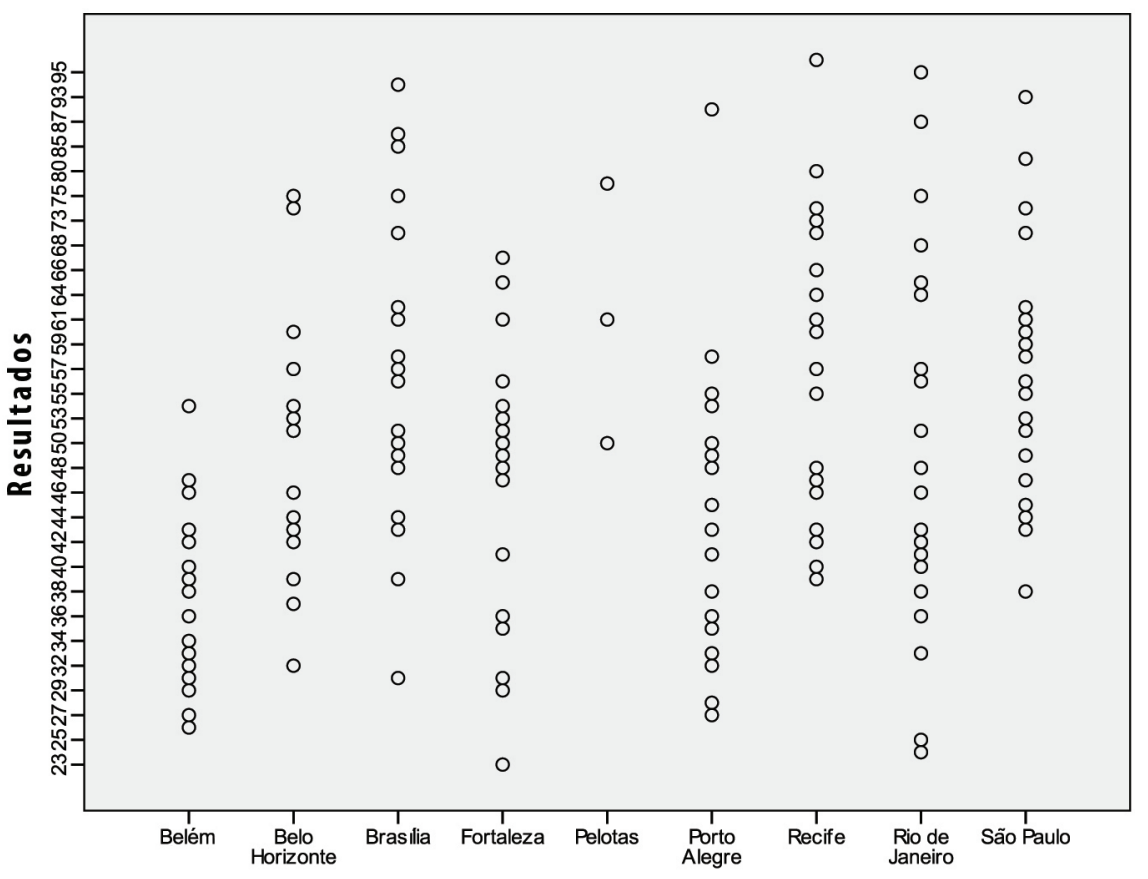

Cidades

Fonte: Altus (2012).

Do ponto de vista substantivo, esses dados indicam que a ideia de democracia disjuntiva - lançada por Caldeira e Holston $(1998,1999)$ para descrever o descompasso existente entre as regras que garantem os direitos civis e os procedimentos pensados para viabilizar a sua institucionalização no cotidiano de atividade das polícias e tribunais - ainda se faz presente no cotidiano de atendimento das delegacias de polícia.

Na visão dos próprios usuários do serviço, as delegacias prestam um atendimento inadequado, do ponto de vista das regras que deveriam respeitar nesse quesito, sendo as maiores falhas as verificadas nas dimensões de tratamento igualitário da população, transparência e prestação de contas e condições de detenção. 
Considerando as pesquisas já realizadas sobre esse tema, o esperado era a verificação de práticas altamente discriminatórias com relação a homens jovens, de cor preta ou parda e de baixa escolaridade. Afinal, esse é o estereótipo dos indivíduos classificados como "bandidos” pelas organizações policiais brasileiras. Nesse quesito, alguns visitantes que se enquadravam nesse perfil, disseram ter se surpreendido com o atendimento prestado pela polícia, mas assinalaram algumas dúvidas sobre a possibilidade de esse tratamento se verificar quando eles voltassem a ser "cidadãos comuns" e não mais participantes de uma pesquisa que avalia a qualidade do serviço policial. Alguns, inclusive, destacaram que, quando presos ou acompanhando familiares presos, receberam o tratamento pela mesma unidade bastante distinto do recebido durante a visita, o que aponta, mais uma vez, para a incapacidade dessas agências em materializar as regras democráticas que deveriam orientar a prestação do serviço.

No item transparência e prestação de contas, os visitantes sublinharam a dificuldade das organizações policiais em se submeter à supervisão civil do ser serviço. Poucas foram as unidades nas quais era possível identificar de imediato quem era o policial, quem era o indivíduo esperando para ser atendido na qualidade de vítima e, ainda, quem era o detido pela prática de um crime. Em um cenário como esse, o policial pode cometer ilegalidades ou desrespeitar aqueles que estão aguardando para serem atendidos sem qualquer tipo de repreensão. Afinal, nem a própria comunidade pode dizer ao certo se ele é, de fato, policial.

Talvez o ponto que mais chame a atenção quanto à disjunção entre regras e procedimentos seja o referente às condições de detenção, já que em duas delegacias foi flagrante o desrespeito aos direitos do indivíduo detido. Em um desses casos, a tortura, apesar de confirmada, não recebeu nenhuma atenção por parte das autoridades responsáveis.

Nesse sentido, cumpre questionar o que esses dados representam do ponto de vista da possibilidade de institucionalização de uma democracia mais substantiva no Brasil. De maneira geral, eles parecem indicar que as agências constituídas para garantir o respeito aos direitos civis, base de qualquer outro, não são capazes de respeitar os regulamentos que orientam o seu funcionamento. Mais do que isso, os dados informam que a disjunção verificada entre regras e procedimentos é tamanha que um indivíduo pode procurar o agente da lei para comunicar a vitimização por crime e sair dessa 
interação morto, apenas por possuir o estereótipo de elemento suspeito de cor padrão.

Os usuários ou potenciais usuários do serviço, contudo, não apenas percebem essa disjunção entre regras e procedimentos como se colocam de acordo com ela, afirmando a dificuldade em recorrer aos serviços policiais quando vítimas de um crime, por temerem retaliações. Exatamente por isso, eles indicam grande surpresa quando são bem recebidos ou encontram uma delegacia preparada para atender as demandas da população em geral e as especificidades que populações minoritárias (como mulheres, idosos e crianças) possuem. Como o mau atendimento e a má qualidade dos serviços são as características esperadas, qualquer sinal de junção entre regras e procedimentos no âmbito das delegacias de polícia causa, se não surpresa, espanto.

Em um cenário como esse, mais do que afirmar que a institucionalização da democracia brasileira ainda tem um longo caminho a percorrer, é indispensável destacar que a qualidade desta é eminentemente contraditória: altamente avançada do ponto de vista procedimental e insatisfatória do ponto de vista substantivo, especialmente, no que diz respeito à garantia dos direitos civis.

\section{Referências}

ALTUS (2012). Police station visitors week: global report. New York: Vera Institute of Justice.

CALDEIRA, Tereza \& HOLSTON, James (1998). "Democracy, law and violence: disjunctions of Brazilian citizenship”, em AGÜERO, Felipe \& STARK, Jeffrey (eds.). Fault lines of democracy in post-transition Latin America. Miami: North-South Center Press.

(1999). "Democracy and violence in Brazil". Society for Comparative Studies in Society and History, v. 41, n. 4, p. 691-729.

CAMPOS, Marcelo Silveira (2010). Crime e Congresso Nacional: uma análise da política criminal aprovada de 1989 a 2006. São Paulo: IBCCRIM.

CANO, Ignacio \& DUARTE, Thais Lemos (2012). 'No sapatinho': a evolução das milícias no Rio de Janeiro (2008-2011). Rio de Janeiro: Fundação Heinrich Böll.

CEJA (2012). Experiencia de los países de América Latina en la investigación de Delitos Complejos. Santiago: Centro de Estudios de Justicia de las Américas. Disponível em: <http://www.cejamericas.org/index.php/ 
biblioteca/boletin-nexos/25-noticias/1274-experiencia-de-los-paisesde-america-latina-en-la-investigacion-de-delitos-complejos $>$. Acessado em 10 nov. 2012.

COELHO, Edmundo Campos (1978). “Da criminalização da marginalidade à marginalização da criminalidade." Revista de Administração Pública. v. 12 , n. 2, p.139-161.

CONECTAS (2009). A privação de liberdade no Espírito Santo. Vitória: CONECTAS.

GIDDENS, Anthony \& TURNER, Jonathan (orgs.) (1999). Teoria social hoje. São Paulo: Editora UNESP.

HAGOPIAN, Frances (2011). "Paradoxes of democracy and citizenship in Brazil". Latin American Research Review, v. 45, n. 3, p. 216 - 227.

HUMAN RIGHTS WATCH (2009). Lethal force: police violence and public security in Rio de Janeiro and São Paulo. Nova York: HRW.

LEVINE, Daniel \& MOLINA, José E. (2011). The quality of democracy in Latin America. Boulder: Lynne Reinner.

MISSE, Michel (2010). "Crime, sujeito e sujeição criminal: aspectos de uma contribuição analítica sobre a categoria 'bandido”. Lua Nova, n. 79, p. 15-38.

(2011). "Autos de resistência": uma análise dos homicídios cometidos por policiais na cidade do Rio de Janeiro (2001-2011). Rio de Janeiro: NECVU.

RIBEIRO, Ludmila; MACHADO, Igor \& SILVA, Klarissa (2012). “Tempo na ou da justiça criminal brasileira: uma discussão metodológica”. Opinião Pública, v. 18, n. 2, p. 355-382.

RODRIGUES, Corinne Davis (2006). "Civil democracy, perceived risk, and insecurity in Brazil: an extension of the systemic social control model”. The Annals of the American Academy of Political and Social Science, n. 605 , p. 242-63.

SINHORETTO, Jacqueline (2011). A justiça perto do povo: reforma e gestão de conflitos. São Paulo: Alameda.

UNODC (United Nations Office on Drugs and Crime) (2011). 2011 global study on homicide: trends, contexts, data. Vienna: UNODC. 


\section{Resumo}

Nos últimos anos, a ciência política brasileira tem se ocupado em estudar de que maneira a democratização dos procedimentos de escolha dos governantes tem sido capaz de se refletir na alteração do modus operandi das instituições estatais, viabilizando, dessa forma, a institucionalização da ideia de democracia substantiva. A partir da análise dos dados referentes a 172 delegacias de polícia, distribuídas em oito estados da federação, e avaliadas no ano de 2010 a partir do emprego de princípios de etnometodologia, problematiza-se como os adjetivos utilizados para qualificação da democracia brasileira (disjuntiva, incompleta, paradoxal) se fazem presentes na rotina da Polícia Civil, apesar de o processo de redemocratização ter sido iniciado neste país há 28 anos.

Palavras-chave: delegacias de polícia, Polícia Civil, democracia, sociologia política, cidadania.

\section{Abstract}

In recent years, political science has been studying how democratization of procedures used for choosing government reflected on changes to the modus operandi of state institutions, in order to facilitate the institutionalization of the idea of substantive democracy in Brazil. From the analysis of data gathered from 172 police stations from eight states and evaluated in 2010, collected by etnomethodology, this paper discusses how the adjectives used to qualify Brazilian democracy (disjunctive, incomplete, paradoxical) are still present in the daily routines of the so-called "Civil Police", besides the fact that redemocratization started in this country 18 years ago.

Keywords: police stations, Civil Police, democracy, political sociology, citizenship.

Recebido em 9 de janeiro de 2013. Aprovado em 9 de março de 2013. 